\title{
Extramural Grant Program
}

\section{Abstracts}

June 10-11, 1997,

Managing Editor

Chicago, Ill., USA

D. Adenau

McGaw Park, Ill., USA

6 figures, 30 tables, 1998 
KARGER

S. Karger

Medical and Scientific Publishers

Basel $\cdot$ Freiburg $\cdot$ Paris $\cdot$ London

New York $\cdot$ New Delhi $\cdot$ Bangkok

Singapore $\cdot$ Tokyo $\cdot$ Sydney
Drug Dosage

The authors and the publisher have exerted every effort to ensure that drug selection and dosage set forth in this text are in accord with current recommendations and practice at the time of publication. However, in view of ongoing research, changes in government regulations, and the constant flow of information relating to drug therapy and drug reactions, the reader is urged to check the package insert for each drug for any change in indications and dosage and for added warnings and precautions. This is particularly important when the recommended agent is a new and/or infrequently employed drug.
All rights reserved.

No part of this publication may be translated into other languages, reproduced or utilized in any form or by any means, electronic or mechanical, including photocopying, recording, microcopying, or by any information storage and retrieval system, without permission in writing from the publisher or, in the case of photocopying, direct payment of a specified fee to the Copyright Clearance Center (see ‘General Information').

(C) Copyright 1998 by S. Karger AG,

P.O. Box, CH-4009 Basel (Switzerland)

Printed in Switzerland on acid-free paper by

Reinhardt Druck, Basel

ISBN 3-8055-6676-X 
1 Introduction

Atkins, R.C. (Melbourne)

Abstracts

Pathophysiology

31 Gene Therapy for Progressive Glomerulosclerosis

Imai, E.; Isaka, Y.; Akagi, Y.; Kaneda, Y. (Osaka)

62 Gene Therapy of Anemia in Chronic Renal Failure

Hamamori, Y.; Kedes, L.H. (Los Angeles, Calif.); Samal, B. (Thousand Oaks, Calif.)

83 Receptor Protein Tyrosine Kinases in Perinatal Developing Rat Kidney

Kee, N.; McTavish, J.A.; Papillon, J.; Cybulsky, A.V. (Quebec)

104 Clinical Indices of Activity of the Nitric Oxide (NO) System; Impact of Advancing Age and Dietary Salt Intake

Baylis, C.; Schmidt, R.; Samsell, L.; Domico, J.; Kuenzig, G.; Sorkin, M. (Morgantown, W. Va.)

125 Regulation of Osteopontin Expression in Proximal Tubules in Experimental Hydronephrosis: Role of Angiotensin II (AlI) Diamond, J.R. (Hershey, Pa.)

156 Age, Renal Perfusion and Function in Indigenous, Island-Dwelling Kuna Amerinds

Hollenberg, N.K.; Martinez, G.; McCullough, M.; Meinking, T.L.; Passan, D.M.; Preston, M.; Rivera, A.; Taplin, D.; Vicaria-Clement, M. (Boston, Mass.)

167 Transfer of Genetically Engineered Macrophages into the Glomerulus Kitamura, M.; Sütö, T.S. (London)

198 The Balance between $\mathrm{C} 5 \mathrm{~b}-9(\mathrm{~m})$ and SC5b-9 in Glomerulonephritis Murphy, B.F.; Macrae, J.L. (Melbourne)
219 Extra-Renal and Not Intra-Renal Absence of Fas Promotes Renal Injury: Systemic Autoimmune Nephritogenic Components Induce CSF-1 and TNF- $\alpha$ in Fas Deficient MRL Mice

Wada, T.; Naito, T.; Coffman, T.; Griffiths, R.;

Kelley, V.R. (Boston, Mass.)

2310 Drug Modulation of Cytokine Expression in IgA Nephropathy: A Clinical and Histopathological Prospective Study

Schena, F.P.; Gesualdo, L.; Grandaliano, G.; Montinaro, V.; Ranieri, E.; Manno, C. (Bari)

2511 Clinical Applications of Recombinant Goodpasture Antigen

Chopra, S.; Turner, A.N. (Aberdeen)

2612 Modulation of Experimental Crescentic Glomerulonephritis by TH2 Cytokines

Holdsworth, S.R.; Kitching, A.R.; Huang, X.R.; Tipping, P.G. (Clayton)

2813 Genetic and Biochemical Abnormalities of Oxygen Radical Generating Enzymes and of von Willebrand Factor in Familial Hemolytic Uremic Syndrome/Thrombotic Thrombocytopenic Purpura (HUS/TTP)

Ruggenenti, P.; Vasile, B.; Noris, M.; Caprioli, J.; Orisio, S.; Macconi, D.; Galbusera, M.; Remuzzi, G. (Bergamo)

2914 Overexpression of the Type II Transforming Growth Factor- $\beta$ (TGF- $\beta$ ) Receptor Inhibits Fibroblast Proliferation Goldberg, H. (Toronto)

3015 Phosphorus and Human Parathyroid Function in vitro

Rodríguez, M.; Almaden, Y.; Hernandez, A.; Canalejo, A.; Torregrosa, V.; Campistol, J.M.; Torres, A. (Barcelona)

31 16 The Role of Genetic Trait in ReninAngiotensin System in Chronic Renal Diseases: Risk for Progression to Chronic Renal Failure and Mortality

Yoshida, H.; Sakai, O.; Kawamura, T.; Kawaguchi, Y.; Hosoya, T. (Tokyo)

\section{KARGER}

\section{(c) 1998 S. Karger AG, Basel} www.karger.com/journals/bpu/bpucont.htm 
3317 A Preliminary Study of Pulsatile GnRH Administration in Hypogonadal Men with End-Stage Renal Disease

Wilkowski, M.; Veldhuis, J.D. (Charlottesville, Va.)

3618 Tubulotoxicity of Reabsorbed Protein

Harris, D.C.H.; Wang, Y.; Rangan, G.; Chen, L.; Tay, T.-C.; Campbell, D. (Westmead)

3819 Effect of Glucose on the Function of the Calcitriol Receptor and Vitamin D Metabolism (VDR)

Hsu, C.H. (Ann Arbor, Mich.)

Renal Osteodystrophy

4020 The Role of Parathyroid Hormone/ Parathyroid Hormone-Related Protein Receptor Regulation in the Skeletal Resistance of Renal Osteodystrophy Picton, M.L.; Hutchison, A.J.; Gokal, R.; Hoyland, J.A. (Manchester)

Acute Renal Failure

4121 Effects of Integrins on Proliferation and Apoptosis of Renal Epithelial Cells after Acute Injury

Wijesekera, D.S.; Zarama, M.J.; Paller, M.S.

(Minneapolis, Minn.)

4322 The Role of Chloride Channels in Oxidant-Induced Membrane Damage in Renal Epithelial Cells

Meng, X.; Filipovic, D.; Reeves, W.B.

(Little Rock, Ark.)

4523 Inflammatory Mechanisms in Systemic Vasculitis

Griffin, S.V.; Lockwood, C.M. (Cambridge)

Cardiovascular

4724 Sympathetic Nerve Activity and Hypertension in Rats with Chronic Renal Failure

Campese, V.M. (Los Angeles, Calif.)

4925 Hyperhomocysteinemia: An Independent Risk Factor for Atherosclerosis in End-Stage Renal Disease Is Related to the Plasma Concentrations of B Vitamins Robinson, K. (Cleveland, Ohio) Increased Cell Growth and NOx Release by Pre-Eclamptic Decidual Endothelial Cells, but Has No Effect on cGMP or Thromboxane Production

Gallery E.D.M.; Campbell, S.; Rowe, J. (St. Leonards)

5427 Connexin-43 Expression in Small Arteries from Normal and Preeclamptic Pregnancies

Umans, J.G.; Hack, B.; Davidson, C.;

Lindheimer, M.D. (Chicago, Ill.)

Concentrations and Its Relation to the Body Fat Content in Chronic Renal Failure

Stenvinkel, P.; Heimbürger, O.; Danielsson, A.; Nordenström, J.; Lönnqvist, F. (Stockholm)

5729 Blood Pressure Independent Changes of Left Ventricular Mass, Cardiac Microcirculation and Cardiac Interstitium in Renal Failure

Amann, K.; Ritz, E. (Heidelberg)

Gene Polymorphisms, Heart Disease and Hemodialysis Patients

Gilfix, B.M. (Québec)

6031 Metabolism of $L p(a)$ in End-Stage Renal Disease

Cain, W.; Smith, P.N.; Rader, D.J. (Philadelphia, Pa.)

6132 Genetic Polymorphisms and Left Ventricular Remodeling in Dialysis

Lipkowitz, M.; Gharavi, A.; Phillips, R.; Roychoudhury, D.; Nash, M.; Gopal, A. (New York, N. Y.)

6233 Ventricular Function after PancreasKidney Transplant

Gaber, A.O.; Hathaway, D.K.; Burlew, B.S.; Wicks, M.N. (Memphis, Tenn.)

34 Platelet-Leukocyte Aggregates in ESRD Mujais, S.K. ( Chicago, Ill.)

6435 Study of the Tissue-Factor Pathway Components in Dialysis Patients Maugard, C.; Branger, B.; Gris, J.C. (Nîmes) 
6536 Inducible Hypertension Due to the

Selective Activation of an Intrinsic Intra-Renal Renin-Angiotensin System in Transgenic Mice

Davisson, R.L.; Ding, Y.; Hardy, D.O.; Zhu, L.-J.; Merrill, D.C.; Catterall, J.F.; Sigmund, C.D. (Iowa City, Iowa/New York, N.Y.)

6737 The Effect of Vitamin E on LDL Oxidation in Dialysis Patients

Jialal, I. (Dallas, Tex.)

Biocompatibility

6838 Neutrophil Oxidative Burst Dysfunction in Uremia

Ward, R.A.; Klein, J.B.; McLeish, K.R.

(Louisville, Ky.)

7039 Production of Interleukin-10 and IL-13 in End Stage Renal Disease and in Hemodialysis and CAPD

Dinarello, C.A. (Denver, Colo.)

7340 The Role of Advanced Glycosylation End Products in Peritoneal Fibrosis and Alteration in Peritoneal Membrane Function in CAPD Patients

Park, M.S.; Jeon, J.S.; Lee, H.B. (Seoul)

7441 Peritoneal Fibrosis in CAPD: The Role of Inflammation on Peritoneal Fibroblast Proliferation in 3-D Culture

Beavis, M.J.; Williams, J.D.; Topley, N. (Cardiff)

7542 Inhibition of Leucocyte Activation during Hemodialysis

Tschesche, H. (Bielefeld)

$7643 \mathrm{RhGH} / \mathrm{rhIGF}-1$ Anabolic Association in Chronic Renal Failure

Fouque, D.; Tabakian, A.; Juillard, L.; Joly, M.O.; Baverel, G.; Beaufrère, B.; Zech, P.; Laville, M. (Lyon)

7844 Collaborative Study on Dialysis Adequacy, Nutrition and Patient Survival in CAPD in Hong Kong

Lo, W.K.; Cheng, I.K.P. (Hong Kong)

7945 Muscle Protein Synthesis and the Control of Muscle Protein Balance in Malnourished Dialysis Patients Garibotto, G. (Genoa)

8146 Adequacy and Nutrition in Indian Haemodialysis Patients

Rao, M. (Vellore)
8247 Acid-Base Status of Korean CAPD Patients: Incidence of Metabolic Acidosis and Its Impact on the Nutritional Status Kang, D.H.; Yoon, K.I.; Han, D.S.; Lee, H.Y.; Kim, Y.S.; Bang, B.K. (Seoul)

8348 Nutritional Status and Diet in Chinese Patients on CAPD

Li, F.K.; Chan, T.M.; Woo, J.C.Y.; Law, W.H.T.;

Ng, P.P.Y. (Hong Kong)

Transport/Adequacy

8449 Registry for Pregnancy in Dialysis Patients

Hou, S. (Chicago, Ill.)

8650 Effect of Vascular Resistance on Urea Compartmentalization: Evidence Supporting a Regional Blood Flow Model Daugirdas, J.T.; Schneditz, D. (Chicago, Ill./Graz)

8951 Increase in Peritoneal Transport of Small Solutes by a Chinese Herb

Liu, F.Y.; Peng, Y.M.; Leypoldt, J.K.; Cheung, A.K. (Changsha/Salt Lake City, Utah)

B2M-Amyloidosis

9052 32-Microglobulin Amyloidosis: ProteinCell Interactions. Biochemical, Biological and Ultrastructural Studies

Gouin-Charnet, A.; García-García, M.; Mourad, G.; Argilés, A. (Montpellier)

9353 Role of the Age-Modified B2-

Microglobulin in the Pathogenesis of Dialysis-Related Amyloidosis

Miyata, T. (Isehara)

Transplantation

9654 Gene Transfer and Gene Therapy in Allografting

Bromberg, J.S. (Ann Arbor, Mich.)

9955 Adhesion Molecules in Xenograft Rejection

d'Apice, A.J.F. (Melbourne)

10056 Morphologic Analysis of Chronic Renal Transplant Rejection

Meyer, T.W.; Suri, D.; Tomlanovich, S.J.; Olson, J.L. (Palo Alto, Calif./San Francisco, Calif.) 
10257 Peripheral Vascular Disease in Kidney/Pancreas Transplant Recipients

Davis, C.L.; Brunzell, J.; Marcovina, S.; Strandness, E. (Seattle, Wash.)

10358 The Chase of a Proteinuria Inducing Factor

Godfrin, Y.; Dantal, J.; Soulillou, J.P. (Nantes)

10559 Glomerular Capillary Wall Injury Contributes to the Hypofiltration of Human Renal Allografts

Guasch, A.; Zayas, C.F.; Someren, A. (Atlanta, Ga.)

10660 Characterisation of Effector Function in Cellular Xenograft Rejection

O’Connell, PJ.; Medbury, H.J.; Lehnert, A.M.; Hawthorne, W.J. (Sydney)

10861 Quantitative Detection of Immune Activation Transcripts as a Diagnostic Tool in Kidney Transplantation

Strehlau, J.; Pavlakis, M.; Lipman, M.; Shapiro, M.;

Vasconcellos, L.; Harmon, W.; Strom, T. B.

(Boston, Mass.)

10962 Asymptomatic Renal Allograft

Rejection: Chronic Rejection or Tolerance?

Grimm. P.C.; McKenna, R.; Nickerson, P.;

Gospodarek, E.; Gough, J.; Jeffery, J.; Rush, D.

(Winnipeg)

11163 Post-Transplant Osteopenia in Diabetic Patients

Josephson, M.A.; Sprague, S.M. (Chicago, Ill.)
11264 Molecular Markers of Posttransplant Focal Segmental Glomerular Sclerosis in Childhood

Strehlau, J.; Ehrich, J.H.H. (Berlin); Strom, T.B.;

Harmon, W. (Boston, Mass.)

11465 Free Radical Mechanism for Cyclosporine-Nephrotoxicity

Salahudeen, A.K.; Wang, C. (Jackson, Miss,)

Viral Hepatitis

11666 Effect of HCV Genotype on Patient and Graft Survival in Renal Transplant Candidates

Natov, S.N.; Bouthot, A.; Lau, J.Y.N.; Ruthazer, R.; Schmid, C.H.; Levey, A.S.; Pereira, B.J.G.; The New England Organ Bank Hepatitis C Study Group (Newton, Mass.)

11867 Molecular Analysis of HCV Transmission in a Hemodialysis Unit

Gretch, D.R. (Seattle, Wash.)

11968 Initiation of Studies to Examine the Epidemiology and Etiology of Glomerular Disease in Lima, Peru

Hurtado, A.; Escudero, E.; Asato, C.; De La Cruz, S.; Urcia, J.; Hurtado, M.E. (Lima); Johnson, R.J. (Seattle, Wash.)

120 Author Index 
This double issue contains the abstracts (camera-ready copy) of the Extramural Grant Program (June 10 - 11, 1997; Chicago, III., USA) and is not available online for technical reasons. 